\title{
Expression, purification and immobilization of tannase from Staphylococcus lugdunensis MTCC 3614
}

\author{
Amballa Chaitanyakumar and M. Anbalagan*
}

\begin{abstract}
Enzymes find their applications in various industries, due to their error free conversion of substrate into product. Tannase is an enzyme used by various industries for degradation of tannin. Biochemical characterization of a specific enzyme from one organism to other is one of the ways to search for enzymes with better traits for industrial applications. Here, tannase encoding gene from Staphylococcus lugdunensis was cloned and suitability of the enzyme in various conditions was analysed to find its application in various industry. The recombinant protein was expressed with $6 \times$ His tag and purified using nickel affinity beads. The enzyme was purified up to homogeneity, with approximate molecular weight of $66 \mathrm{kDa}$. Purified tannase exhibited specific activity of about $716 \mathrm{U} / \mathrm{mg}$. Optimum enzyme activity was found to be $40^{\circ} \mathrm{C}$ at pH 7.0. Biochemical characterization revealed; metal ions such as $\mathrm{Zn}^{2+}, \mathrm{Fe}^{2+}, \mathrm{Fe}^{3+}$ and $\mathrm{Mn}^{2+}$ inhibited tannase activity, and SDS at lower concentration, increased tannase activity. Non polar organic solvents increased the tannase activity and polar solvents inhibited the tannase activity. Tannase immobilization studies show protection of the enzyme under wide range of $\mathrm{pH}$ and temperature. Also in this study we report a method for recovery and repeated use of the tannase.
\end{abstract}

Keywords: Tannase, S. lugdunensis, Overexpression, E. coli

\section{Introduction}

Enzyme catalysed reactions are more preferred over chemical catalyst due to its several advantages; hence enzymes find a wide variety of applications in various industries (Gurung et al. 2013; Cherry and Fidantsef 2003). Microbes serve as a source for numerous enzymes with wide industrial applications (Demain 2000). Limitations in the quantity of enzyme produced by an organism compels, cloning and over expression of microbial enzymes regularly. Moreover, cloning of genes encoding enzymes of industrial importance is an essential step for engineering of enzymes for better traits. Comparison of an enzyme activity across different species (Taylor et al. 2002), screening of enzymes with random mutations (Cherry and Fidantsef 2003) and introduction of specific mutations in the enzymes (Neylon 2004; Cherry

\footnotetext{
*Correspondence: anbalagan.m@vit.ac.in

School of Bio-Sciences and Technology, VIT University, Vellore 632014, India
}

and Fidantsef 2003) are some of the methods to obtain enzymes for industrial use with desirable traits for various industrial applications.

Tannins are polyphenolic compounds produced by plants in order to protect themselves from invading microorganisms and herbivores (Buzzini et al. 2008). Tannin causes indigestion in herbivores when ingested; sometimes leading to death when ingested in more quantities (Butler 1992). Microbes produce tannase enzyme as a strategy to protect itself from tannin. Tannase enzyme (Tannin acyl hydrolase EC 3.1.1.20) hydrolyzes ester bonds in tannin to produce glucose and gallic acid.

Tannase is widely used in industries such as food, chemical, pharmaceuticals, breweries, tannery effluent treatment and production of animal feed (Aguilar et al. 2007). Tannase is also widely used for the production of gallic acid, which is a key intermediate required for the synthesis of an antibiotic drug, trimethoprim and used to produce propyl gallate, which is mainly used as an antioxidant in fats, oils and beverages (Miura et al. 2013). Gallic 
acid is also used in the fabrication of semiconductors, dyes and in photographic revelation (Chávez-González et al. 2012). Thus tannase finds its application in several industries.

Given its wide range of applications, there is a need for large scale production of this enzyme and more studies are required for production of good quality and quantity of tannase. Given the little amount of tannase produced by the micro-organisms, cloning and over expression of tannase gene is the feasible process to decrease production cost of the enzyme. Hatamoto et al. (1996) reported first cloning and expression of tannase from Aspergillus oryzae. Fungal tannase gene heterologously expressed in Saccharomyces cerevisiae and Pichia pastoris produced high amounts of recombinant tannase. Fungal tannase is made up of more than one subunit (Yao et al. 2014), which makes it difficult for over expression and purification. Compared to fungal tannase, bacterial tannase is made up of single subunit (Ren et al. 2013), which makes, cloning over expression and purification very easy.

Improvement of enzymes with desired industrial properties requires a complex and tedious methods of protein engineering or screening for mutant enzymes with desired activities (Neylon 2004; Cherry and Fidantsef 2003). Comparison and characterization of enzymes produced across different organisms, will give us an idea about choosing better enzymes with desired industrial properties. As mentioned before, tannase enzyme has been cloned and characterized in different organism, in the current study, for the first time, tannase gene from $S$. lugdanensis have been cloned, expressed, characterized and immobilized. The properties of the enzyme are compared with other bacterial tannase enzymes reported earlier. Also the immobilized enzyme was characterized suit its application in various industries.

\section{Materials and Methods Microorganisms}

Bacterial strains S. lugdunensis MTCC3614 was acquired from MTCC (India), and cultured in Trypticase soya broth medium at $35{ }^{\circ} \mathrm{C}$ in a temperature controlled shaker at $150 \mathrm{rpm}$. For transformation and expression studies, E. coli DH5 $\alpha$ and E. coli BL21 (DE3) were cultured in Luria-Bertani broth (LB) and incubated overnight at $37^{\circ} \mathrm{C}$.

\section{Cloning of tannase gene tanA}

Genomic DNA was extracted from S. lugdunensis by CTAB $\mathrm{NaCl}$ method (Willner et al. 2012). Primers with the following sequences were synthesized in sigma-aldrich (Bangalore). SlF (gtacGGATCCatgaaaa agactttc) and SIR (ggccCTCGAGctatttttattaatac) (additional nucleotides indicated in lower case, restriction sequence in higher case and the gene sequence in italics). A BamHI restriction site was introduced in the forward primer (SIF) and to the reverse primer (SIR) XhoI restriction site was introduced. The $\tan \mathrm{A}$ gene (NCBI accession number AB244239) along with flanking restriction sites was PCR amplified using the above mentioned primers along with genomic DNA isolated from S. lugdunensis as template. PCR conditions included an initial denaturation at $95^{\circ} \mathrm{C}$ for $5 \mathrm{~min}$, followed with 30 cycles of $95{ }^{\circ} \mathrm{C}$ for $1 \mathrm{~min}, 44{ }^{\circ} \mathrm{C}$ for $1 \mathrm{~min}, 68^{\circ} \mathrm{C}$ for $2 \mathrm{~min}$ and final extension at $68^{\circ} \mathrm{C}$ for $10 \mathrm{~min}$. Prime STAR GXL DNA polymerase (TaKaRa) was used for reaction. Plasmid pET28a was obtained from Novagen company (Madison USA) and amplified in E. coli (DH5 $\alpha)$. For plasmid isolation, Bio Basic plasmid isolation kit (India) was used. Restriction enzymes $B a m \mathrm{HI}$ and XhoI were obtained from NEB and NEB double digest standard protocols followed for restriction digestion of pET28a vector and the purified PCR product. After restriction digestion, pET28a and PCR product were purified on agarose gel using Bio-basic gel purification Kit. Gel purified pET28a and PCR products were mixed in the ratio of 1:3 and ligation reaction was carried out using TaKaRa ligation kit. The ligated product was transformed into chemically competent $E$. coli (DH5 $\alpha$ ) cells and plated on LB agar plate with $35 \mu \mathrm{g} / \mathrm{ml}$ of kanamycin. Single colonies from the plate was randomly picked and inoculated individually in liquid LB broth with kanamycin for plasmid isolation. Plasmids isolated from these clones were screened for presence of inserts by restriction digestion, using same restriction enzymes used for cloning. The authenticity of clone was tested by sequencing the insert and comparing the DNA sequence with NCBI data base.

\section{Protein expression and purification}

Recombinant pET28a vector (referred as ptanET 28a) was transformed into E. coli (BL21DE3) and used for expression and purification of tannase enzyme. The E. coli (BL21 DE3) containing ptanET 28a vector was inoculated in LB broth with kanamycin and grown overnight in a $37{ }^{\circ} \mathrm{C}$ incubator shaker. Overnight culture was diluted with fresh medium to obtain a culture OD of 0.1 and the culture was grown until the OD value 0.6 was reached. For induction of protein from the plasmid, this culture was incubated with $1 \mathrm{mM}$ isopropyl $\beta$-D1-thiogalactopyranoside (IPTG) at room temperature $(16 \mathrm{~h})$. Culture without IPTG was grown under identical condition was used as control. At the end of incubation, cultures were centrifuged at $5000 \mathrm{rpm}$ for $5 \mathrm{~min}$ at $4{ }^{\circ} \mathrm{C}$, the supernatant was removed and pellet was further 
processed for protein purification. To the cell pellet, phosphate buffer ( $\mathrm{pH}$ 7.0) was added and cells were lysed by sonication. Whole cell lysate were cleared by centrifuging at $10,000 \mathrm{rpm}$ for $10 \mathrm{~min}$ at $4{ }^{\circ} \mathrm{C}$, the soluble protein solution in the supernatant was further processed for recombinant protein purification.

Nickel NTA agarose resin was used for separating $6 \times$ His tagged recombinant tannase from the whole cell lysate. Nickel NTA resin was equilibrated for $1 \mathrm{~h}$ with binding buffer $\left(50 \mathrm{mM} \mathrm{NaH}_{2} \mathrm{PO}_{4}, 300 \mathrm{mM} \mathrm{NaCl}, 10 \mathrm{mM}\right.$ imidazole, $\mathrm{pH}$ 8.0). Buffer equilibrated resin $(0.5 \mathrm{ml})$ was separated and added to the cell lysate. The suspension was mixed gently for $1 \mathrm{~h}$ at room temperature in order to allow binding of recombinant tannase to nickel NTA agarose. At the end of incubation period, the contents were centrifuged at $3000 \mathrm{rpm}$ for $5 \mathrm{~min}$ to sediment the resin. The supernatant was carefully removed and pellet was washed thrice with ten volumes of wash buffer $(50 \mathrm{mM}$ $\mathrm{NaH}_{2} \mathrm{PO}_{4}, 300 \mathrm{mM} \mathrm{NaCl}, 20 \mathrm{mM}$ imidazole pH 8.0). After the last wash, the supernatant was removed and pure enzyme was eluted by adding one volume of elution buffer $\left(50 \mathrm{mM} \mathrm{NaH} \mathrm{PO}_{4}, 300 \mathrm{mM} \mathrm{NaCl}, 250 \mathrm{mM}\right.$ imidazole $\mathrm{pH}$ 8.0) and mixed thoroughly for $10 \mathrm{~min}$ at room temperature. At the end of incubation time, mixture was centrifuged at $3000 \mathrm{rpm}$ for $5 \mathrm{~min}$. The supernatant were collected and transferred to fresh tubes and stored at $4{ }^{\circ} \mathrm{C}$. Purity of the enzyme was determined by sodium dodecyl sulfate polyacrylamide gel electrophoresis (SDSPAGE) analysis.

\section{Enzyme activity}

Tannase enzyme activity was determined by rhodanine method (Sharma et al. 2000). Rhodanine specifically reacts with gallic acid to form chromogen but not other phenolic compounds. Tannase activity was calculated based on the liberation of gallic acid in specific enzymatic assay conditions. Solution containing $50 \mu \mathrm{l}$ of enzyme was incubated with $100 \mu \mathrm{l}$ of substrate methyl gallate $\left(0.01 \mathrm{M}\right.$ concentration) for $5 \mathrm{~min}$ at $37^{\circ} \mathrm{C}$. At the end of incubation time, the reaction was stopped by adding $300 \mu \mathrm{l}$ methanolic rhodanine $(0.667 \%)$ and the tubes were incubated for $3 \mathrm{~min}$ at room temperature. To all tubes $100 \mu \mathrm{l}$ of $0.5 \mathrm{M} \mathrm{KOH}$ and water is added to a final volume of $2 \mathrm{ml}$ before taking reading at $520 \mathrm{~nm}$. Control tubes were incubated with same concentration of heat denatured enzyme along with substrate and methanolic rhodanine, blank was made without enzyme. Amount of gallic acid liberated was estimated using standard gallic acid calibration curve. One unit of tannase was taken as the amount of enzyme required for liberating one $\mu \mathrm{mol}$ of gallic acid per ml per min. Amount of protein present in the sample was estimated using protocol of Bradford with BSA as standard $1 \mathrm{mg} / \mathrm{ml}$.

\section{Immobilization}

Crude tannase (2000 Units/ml) was slowly mixed with $10 \mathrm{ml}$ of sodium alginate (5\%) by avoiding air bubbles. The tannase sodium alginate mixture was added drop by drop into ice cold $0.7 \% \mathrm{CaCl}_{2}$ solution with continuous stirring. The beads thus formed were transferred to fresh $0.7 \% \mathrm{CaCl}_{2}$ solution and stored for $2 \mathrm{~h}$ at $4{ }^{\circ} \mathrm{C}$ to strengthen the beads. The beads were then washed with $0.2 \mathrm{~mm}$ phosphate buffer $(\mathrm{pH}$ 7.0) for removing any unbound protein. The immobilization yield was determined by dividing immobilized beads specific activity by total enzyme specific activity used for immobilization. The beads were then stored at $4{ }^{\circ} \mathrm{C}$ for further analysis.

\section{Effect of temperature}

The effect of temperature on tannase activity was studied for crude, purified and immobilized enzyme at different temperatures $\left(4,10,20,30,40,50,60\right.$ and $\left.70{ }^{\circ} \mathrm{C}\right)$. The enzymatic reaction mixture was incubated for $5 \mathrm{~min}$ in the above mentioned temperatures and the enzyme activity was measured as mentioned above.

\section{Effect of $\mathrm{pH}$}

Effect of $\mathrm{pH}$ on tannase activity was studied by incubating crude, purified and immobilized enzymes at different $\mathrm{pH}(3.0-9.0)$ and constant temperature $40{ }^{\circ} \mathrm{C}$ for $5 \mathrm{~min}$. $\mathrm{pH}$ study was performed using buffers such as $0.02 \mathrm{M}$ citrate buffer ( $\mathrm{pH} 3.0-5.0), 0.02 \mathrm{M}$ phosphate buffer $(\mathrm{pH}$ 6.0-7.0) and 0.02 $\mathrm{M}$ tris buffer (pH 8.0-9.0).

\section{Effects of additives}

Effect of additives on tannase activity was studied by incubating purified tannase with $1 \%$ of different additives such as Tween20, Tween80, TritonX 100, $\beta$-mercaptoethanol, sodium dodecyl sulfate (SDS) and ethylenediaminetetraacetic acid (EDTA) for $30 \mathrm{~min}$ at room temperature. The residual tannase was collected for estimation of enzyme activity. Purified tannase without additives was kept as control and its activity was taken as $100 \%$ activity and based on this relative activity of tannase with different additives were calculated.

\section{Effects of metal ions}

Effects of metal ions on tannase activity was determined by incubating purified tannase with metal ions such as $\mathrm{MgCl}_{2}, \mathrm{CaCl}_{2}, \mathrm{NaCl}_{2}, \mathrm{ZnCl}_{2}, \mathrm{FeCl}_{2}, \mathrm{MnCl}_{2}, \mathrm{KCl}$ and $\mathrm{FeCl}_{3}$ for $30 \mathrm{~min}$ at room temperature for three different concentrations $(1,5$ and $10 \mathrm{mM})$. After incubation residual tannase was collected and used for determination of tannase activity. Purified tannase activity in the absence of any metal ions was taken as control and its relative activity was considered $100 \%$ which was used to calculate relative activity of the tannase with different metal ions. 


\section{Effects of organic solvents}

Purified tannase was pre-incubated with different concentrations (20, 40 and $60 \%)$ of organic solvents such as methanol, dimethyl sulfoxide (DMSO), hexane, isoamyl alcohol, toluene, butanol and benzene for $30 \mathrm{~min}$ at room temperature to determine the effects of organic solvents on the tannase. Purified tannase in the absence of any organic solvent was taken as control and its relative activity as considered $100 \%$ activity of tannase and calculated tannase relative activity after incubated with organic solvents.

\section{Reusability of immobilized enzyme}

The reusability of immobilized tannase on calcium alginate beads was studied by incubation of $0.5 \mathrm{~g}$ of immobilized beads with $1.5 \mathrm{ml}$ of $0.01 \mathrm{M}$ methyl gallate and $1.5 \mathrm{ml}$ of phosphate buffer $(\mathrm{pH} 7.0)$ for $30 \mathrm{~min}$ at $40{ }^{\circ} \mathrm{C}$. Activity was estimated by using methyl rhodanine method. The same gel beads were then washed with phosphate buffer and re-incubated with another substrate solution; this procedure was repeated for 15 times, and the initial activity of the enzyme was considered as $100 \%$. The relative activity was expressed as a percentage of the starting operational activity.

\section{Results}

\section{Cloning and expression of tannase}

Tannase being an important commercial enzyme, more variants of enzyme from microbial sources need to be characterized. In order to characterize tannase from $S$. lugdunensis, tannase encoding gene from S. lugdunensis was PCR amplified from its genomic DNA using specific primers. Separation of PCR product on agarose gel electrophoresis revealed a fragment of $1.8 \mathrm{~kb}$ size as shown in the Fig. 1. Tannase gene ORF was cloned into BamHI and XhoI site of pET 28a vector multiple cloning site. Presence of tannase gene in the vector was confirmed by a) Release of cloned ORF with BamHI and XhoI b) Sequencing the insert in the recombinant vector. As shown in Fig. 2, digestion of recombinant plasmid with BamHI and $X h o I$ released the insert which was absent in control vector. DNA sequencing and comparison of sequences with reference sequence in NCBI database revealed a $100 \%$ match.

\section{Induction and protein purification}

After confirming the presence of tannase gene ORF in correct reading frame with $6 \times$ His sequence of the $\mathrm{pET}$ 28a expression vector, expression studies were carried out with ptanET 28a in BL-21 (DE3) strain. BL-21 bacteria carrying the plasmid was induced with IPTG for $16 \mathrm{~h}$ and protein profile was compared with the un-induced Bl-21 bacteria, and tannase with $6 \times$ His tag was purified
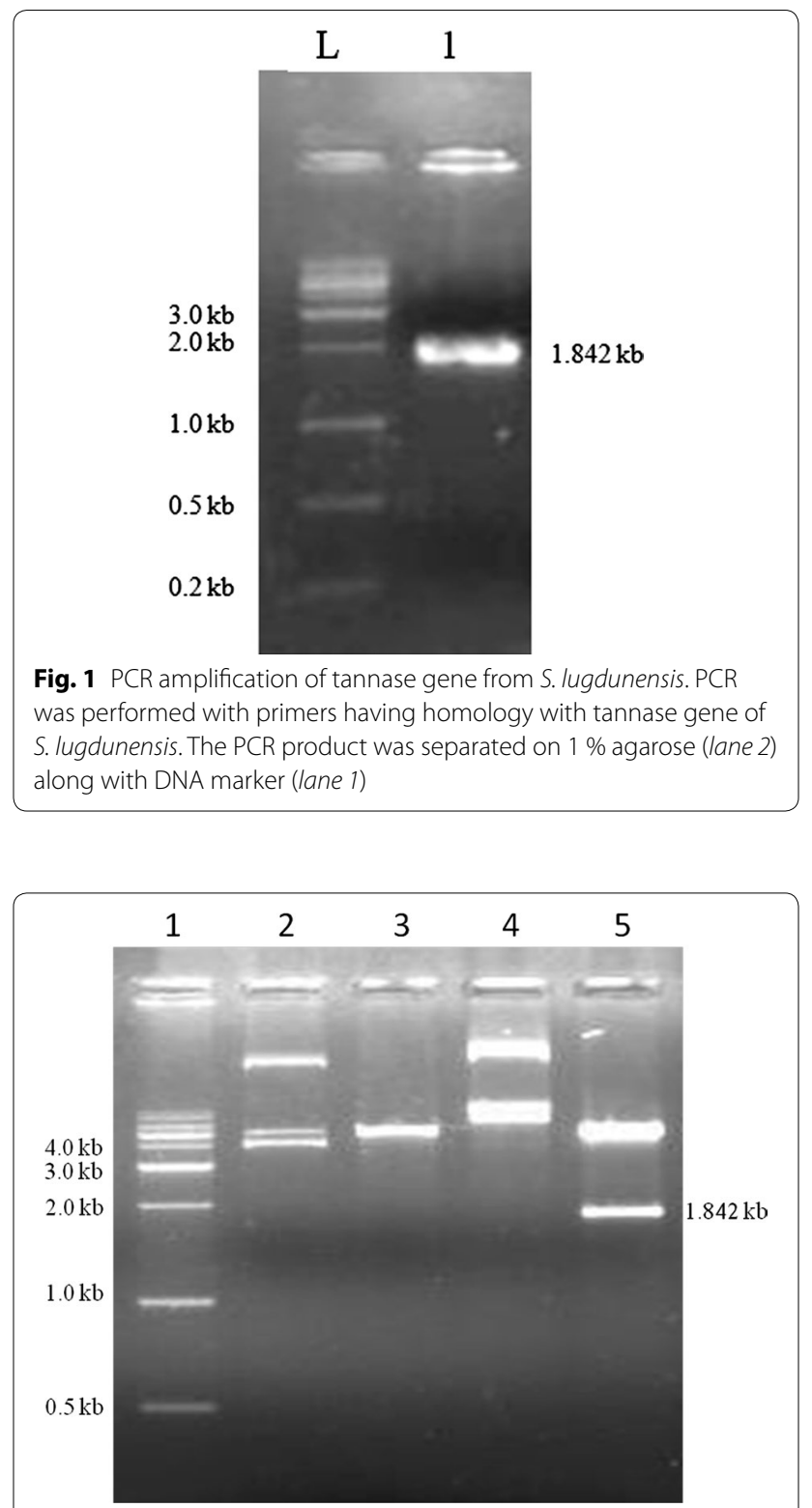

Fig. 2 Release of insert from pET 28a vector with restriction enzymes. Recombinant vector and empty vector were incubated with or without restriction enzymes used for cloning for $2 \mathrm{~h}$ at $37^{\circ} \mathrm{C}$. The products were separated on $1 \%$ agarose gel. Lane 1: $1 \mathrm{~kb}$ marker; Lane 2: pET28a vector without enzymes; Lane 3: pET28a vector with restriction enzymes; Lane 4: Recombinant pET28a without restriction digestion; Lane 5: Recombinant PET28a vector with restriction digestion

from whole cell lysate using Ni NTA beads. As shown in the Fig. 3 protein samples from induced and un-induced BL-21 bacteria and purified tannase was separated on SDS-PAGE and stained with Coomassie blue. Ni NTA purification yielded $100 \%$ pure protein as shown in the gel as a single band of molecular weight $66 \mathrm{kDa}$. The size 


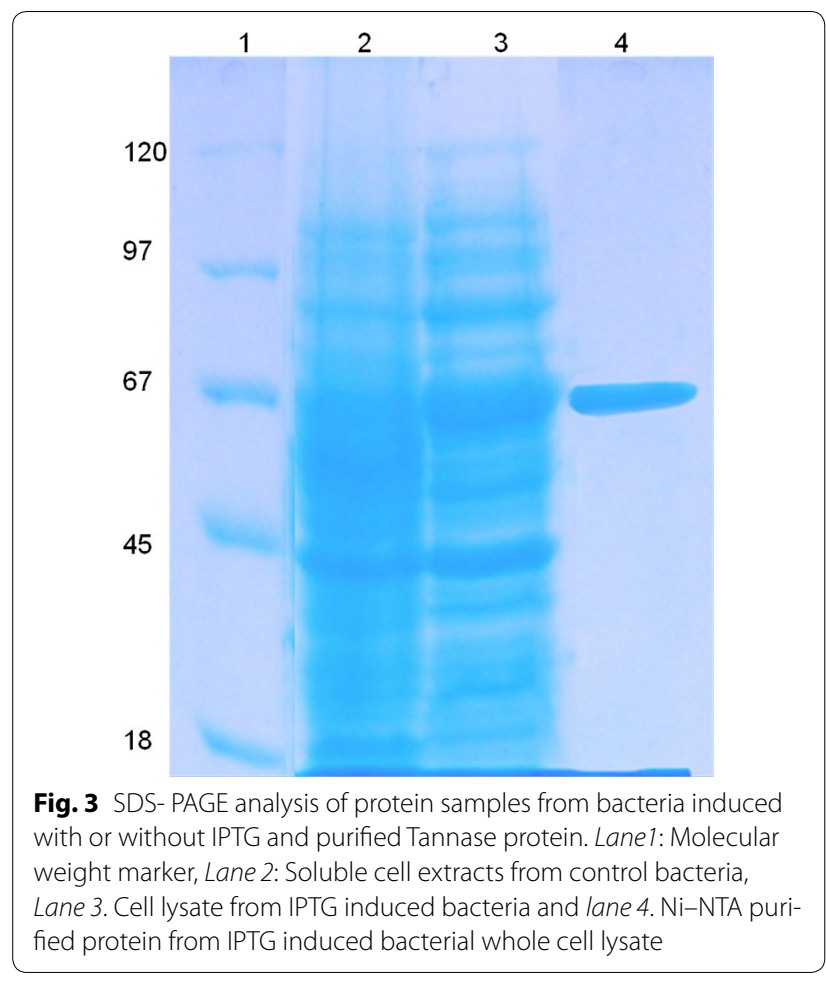

of the band matched with the induced tannase in the whole cell lysate of BL-21.

\section{Effect of temperature}

The activity of tannase in (1) crude (2) purified and (3) immobilized tannase was tested and results are shown in Fig. 4. Highest tannase activity was found to be $40{ }^{\circ} \mathrm{C}$ for the three forms of tannase. However at lower temperature $\left(4{ }^{\circ} \mathrm{C}\right)$ immobilized tannase showed highest activity $(80 \%)$ followed by crude $(60 \%)$ and purified tannase (40\%). The same trend was observed at higher temperature $\left(70{ }^{\circ} \mathrm{C}\right)$; immobilized $(39 \%)$, crude $(10 \%)$ and no detectable activity with purified tannase.

\section{Effect of $\mathrm{pH}$}

At $40{ }^{\circ} \mathrm{C}$ effect of $\mathrm{pH}$ on tannase activity was measured for (1) crude (2) purified and (3) immobilized tannase and results are shown in Fig. 5. At pH 7.0 highest activity was found for the three forms of tannase. At extreme condition (both high and low $\mathrm{pH}$ ) immobilized tannase showed better activity compare with crude and purified tannase. At $\mathrm{pH}$ 3.0, immobilized tannase activity $29 \%$ and $\mathrm{pH} 9.0$ immobilized tannase activity $95 \%$ was observed.

\section{Effects of additives}

Effects of different additives on tannase activity were monitored under optimum temperature and $\mathrm{pH}$. Out

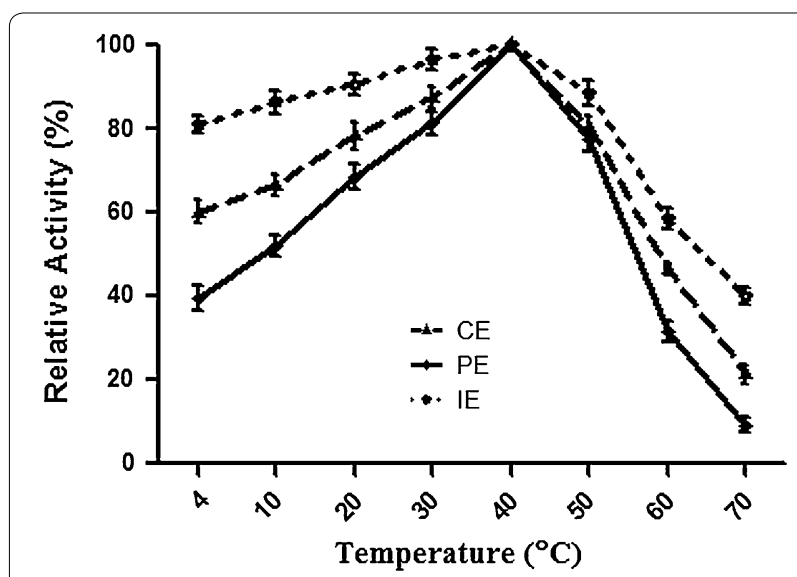

Fig. 4 Effect of temperature on tannase activity of S. lugdunensis. Enzyme activity at different temperature was measured using CE crude enzyme, PE purified enzyme and IE immobilized enzyme. Values show relative levels at optimum temperature $\left(40{ }^{\circ} \mathrm{C}\right)$

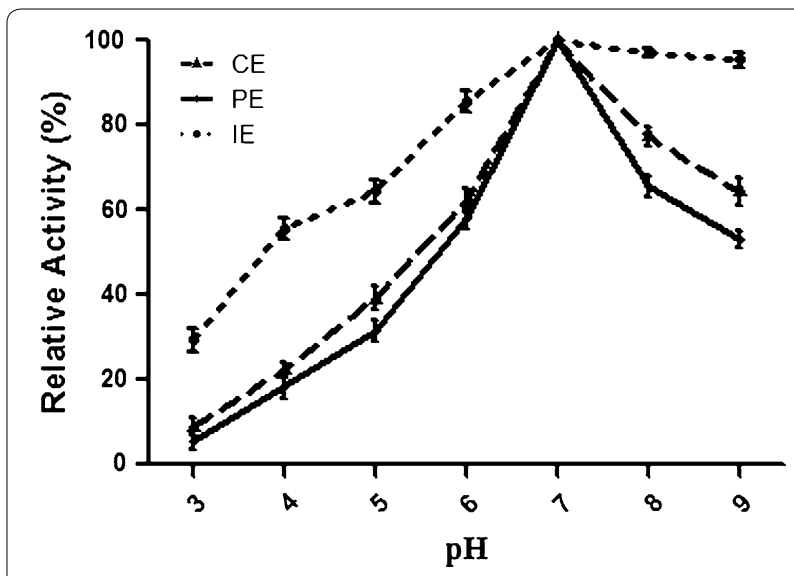

Fig. 5 Effect of pH on tannase activity of S. lugdunensis. Enzyme activity at different $\mathrm{pH}$ was measured using CE crude enzyme, $P E$ purified enzyme and IE immobilized enzyme. Values show relative levels at optimum $\mathrm{pH}$ (7.0)

of different detergents included in the study as listed in Fig. 6. Only SDS at concentration of $1 \%$ increased $20 \%$ of the tannase activity. At $1 \%$ concentration EDTA shows slight inhibition (15\%) and $\beta$-mercaptoethanol completely inhibited tannase activity at $1 \%$ concentration and other additive did not show any significant changes.

\section{Effect of metal ions}

Since several enzymes uses metal ions as co-factors, influence of several metal ions on tannase activity was tested at optimum temperature and $\mathrm{pH}$ (Fig. 7). Out of several metal ions tested, $\mathrm{Na}^{+}$ion increased the enzyme activity by $10 \%$ at $1 \mathrm{mM}$ concentration, generally 


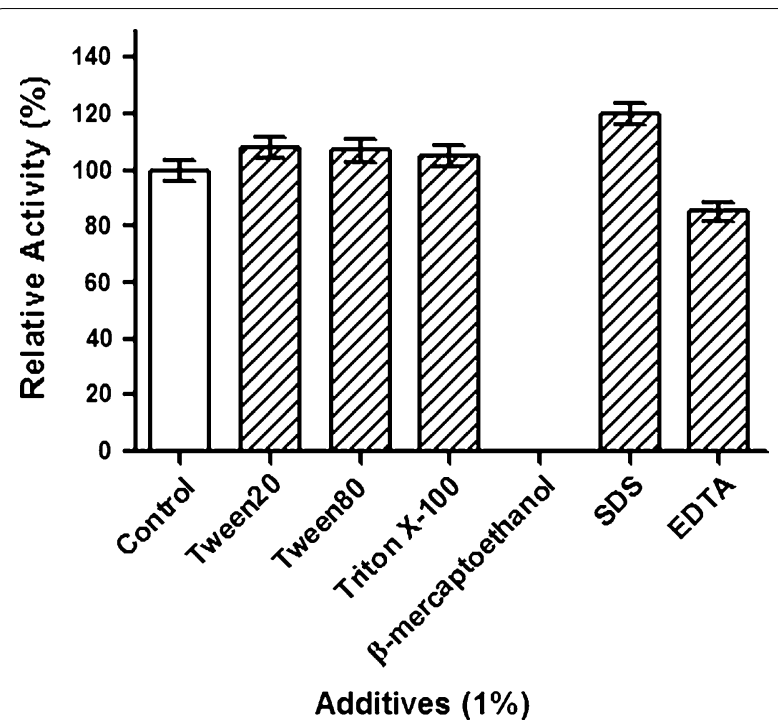

Fig. 6 Effect of pre-incubation of detergents on S. lugdunensis tannase activity. Purified tannase was incubated for 30 min with or without $1 \%$ of above mentioned detergents and enzyme assay was carried out. Values represent relative to control

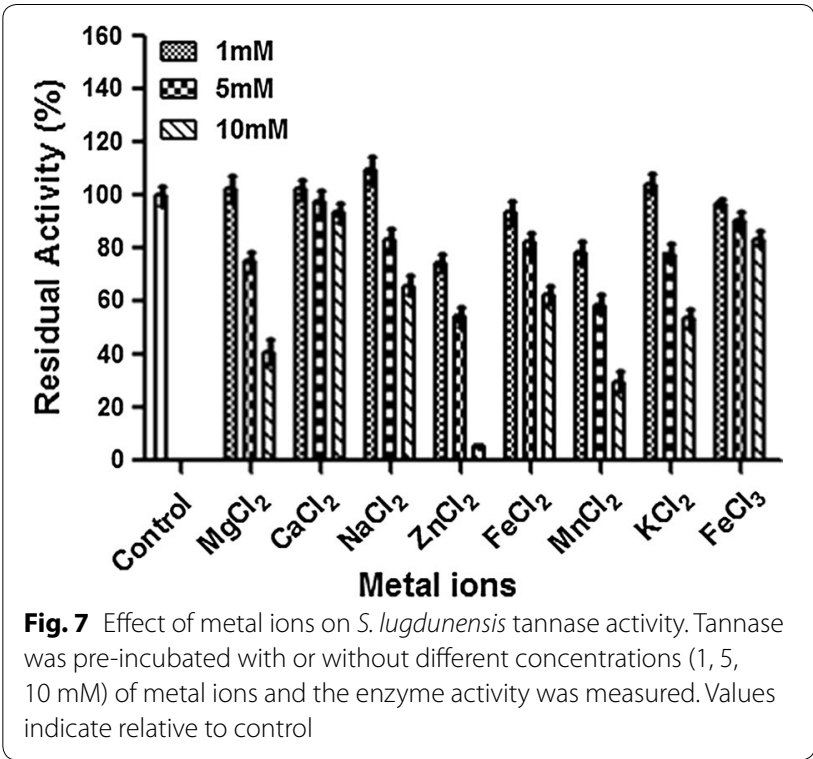

inhibition of tannase activity was observed in presence of high concentration of ions (except for $\mathrm{Ca}^{2+}$ ions).

\section{Effect of organic solvents}

Effect of organic solvents on tannase activity was measured. The tannase activity was tested, in presence of various organic solvents in different concentrations Fig. 8. Generally non-polar solvents (Hexane, Toluene, and Benzene) increased the tannase activity and polar solvents (Methanol, DMSO, Isoamyl alcohol and Butanol)

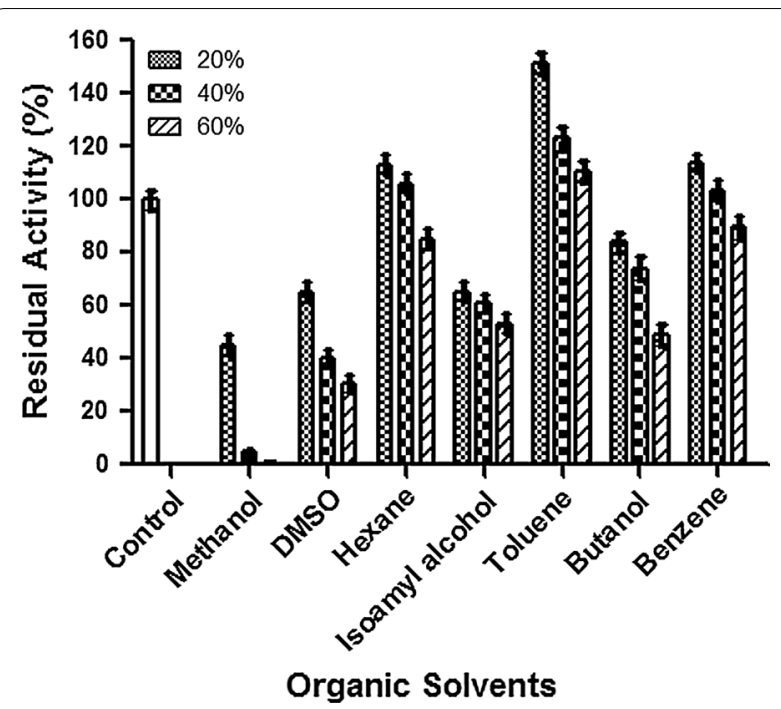

Fig. 8 Effect of organic solvents on S. lugdunensis tannase activity. Tannase was pre-incubated for $30 \mathrm{~min}$ at room temperature with different percentage of below given list of organic solvents and activity of the enzyme was measured. Values indicate relative to control values

decreased the tannase activity. Toluene at $20 \%$ concentration enhanced tannase activity by $50 \%$, hexane and benzene at $20 \%$ concentration increased enzyme activity $15 \%$. DMSO and iso-amylalcohol at $20 \%$ could inhibit the tannase by $35 \%$ of activity; and methanol at same concentration shows $56 \%$ inhibition of tannase activity.

\section{Stability and reusability of immobilized tannase}

Immobilized tannase reusability and stability at operational conditions were studied up to 15 cycles. Immobilized beads showed $80 \%$ activity up to seven cycles, more than $50 \%$ activity was observed even after 15 cycles Fig. 9.

\section{Discussion}

Microbes produce a variety of enzymes to cater their metabolic needs under different physiological conditions. Tannase is one such enzyme produced by microbes to protect themselves from tannin mediated toxicity and to generate glucose from tannin under scarcity of glucose in the surrounding environment (Jiménez et al. 2014b). Tannase is expressed in the microbes only when it is required (Jana et al. 2014; Kumar et al. 2015), therefore, the tannase produced by the microorganisms are so little, that it cannot cater the needs of industries. Hence, cloning and expression of tannase is the way to produce large quantity of tannase. In this regard several studies have reported cloning and expression of tannase from different microorganisms. Bacterial tannase gene was 


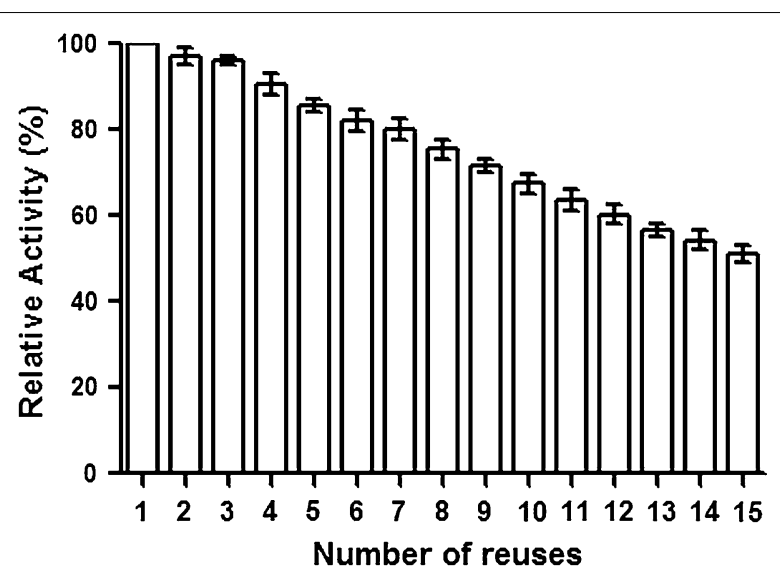

Fig. 9 Relative activity of re-used immobilized tannase. Immobilized tannase beads were incubated with substrate and enzyme assay was carried out. At the end of incubation period, beads were recovered and re incubated with the substrate and enzyme activity was measured. Numbers indicate, number of times the same beads were used in the assay

cloned expressed and characterized from Lactobacillus plantarum, (Iwamoto et al. 2008), (Curiel et al. 2009) and (Ueda et al. 2014) Streptococcus gallolyticus (Jiménez et al. 2014a) and Enterobacter sp. (Prakash and John 2011).

Given the wide application of tannase in different industries, different type of tannase that can work at wide range of physical parameters such as temperature, $\mathrm{pH}$, ionic strength, presence of detergent and organic solvents needs to be identified. Tannase like any other enzyme is made up of amino acids, the amino acid composition and number will determine the performance of the enzyme at the above mentioned parameters. Though several tannase encoding gene has been characterized before, tannase enzyme from S. lugdunensis has not been characterized so far. Given the reason that tannase encoded by $S$. lugdunensis differ in the number and composition of amino acids with tannase produced by other organisms (Noguchi et al. 2007). In this study for the first time we have characterized tannase from $S$. lugdunensis.

As mentioned before, bacterial tannase gene was cloned expressed and characterized from different bacterial species, in order to study if tannase from S. lugdunensis has any advantages with respect to industrial applications, tannase encoding gene was cloned, over expressed, characterized and immobilization studies were carried out. $S$. lugdunensis genome encodes tannase gene of size 1842 base pairs, genomic DNA PCR with primer pairs annealing to tannase gene of $S$. lugdunensis gave a PCR product of size $1.8 \mathrm{~kb}$ indicating PCR amplification of tannase encoding gene from the bacteria (Fig. 1). This PCR product was cloned into pET28a vector. Compared to control vector, release of $1.8 \mathrm{~kb}$ product from ptanET28a recombinant vector using restriction enzymes were used to clone the PCR product into the vector (Fig. 2), proves the construction of recombinant expression vector for tannase. Sequencing and alignment of insert sequence with NCBI data base revealed; the insert shared $100 \%$ homology with tannase gene of S. lugdunensis.

Comparison of whole cell lysate obtained from IPTG induced and un-induced bacterial culture on SDS-PAGE, revealed a prominent band of size $66 \mathrm{kDa}$ present only in IPTG induced samples (Fig. 3). In silico translation of S. lugdunensis tannase gene produced a $66 \mathrm{kDa}$ protein and bacteria with ptanET28a produced identical $66 \mathrm{kDa}$ protein, confirming our recombinant vector express tannase gene from $S$. lugdunensis. In this regard Noguchi et al. (2007) also reported S. lugdunensis encodes tannase enzyme with molecular weight of $66 \mathrm{kDa}$.

In order to detect tannase activity and for characterization of the enzyme, rhodanine assay (Sharma et al. 2000) was used. Since pET28a is designed to express the recombinant protein as a $6 \times$ His tagged version, the over expressed tannase was purified using Ni NTA beads, up to the purity of no detectable impurities was present on SDS-PAGE stained with Coommassie blue stain (Fig. 3). Purified form of tannase was used in all enzymatic assays involving characterization of this enzyme with a specific activity of about $716 \mathrm{U} / \mathrm{mg}$. This was higher than other reported studies $(577 \mathrm{U} / \mathrm{mg}$ ) (Jiménez et al. 2014a), (84.3 U/mg) (Iwamoto et al. 2008) and (13.63 U/mg) (Prakash and John 2011).

Most of the bacterial tannase exhibit an optimal temperature in the range between 30 and $40{ }^{\circ} \mathrm{C}$ (ChávezGonzález et al. 2012). S. lugdunensis recombinant enzyme (crude, purified and immobilized tannase forms) showed similar optimal temperature of about $40{ }^{\circ} \mathrm{C}$ (Fig. 4). Studies conducted to identify maximum and minimum tolerant temperature for the tannase revealed; immobilized tannase showed $90 \%$ activity at $50{ }^{\circ} \mathrm{C}$, crude tannase showed $80 \%$ activity and purified tannase gave $75 \%$ activity at the same temperature. Similarly at $4{ }^{\circ} \mathrm{C}$, immobilized tannase shows $80 \%$ activity, crude and purified tannase showed 60 and $40 \%$ activity respectively (Fig. 4). These results suggest that immobilization of tannase protects the tannase activity at both above and below optimal temperature. Previous reports also suggest that immobilization of tannase protects the enzyme activity at both higher and lower than optimal temperature (Iyer and Ananthanarayan 2008). These observations suggest that immobilization of tannase can find its applications in industries such as juice production, wine production, and instantaneous tea production requiring clarification of tannin at lower temperatures. In relation to this it has been reported that immobilization process 
significantly improved thermo stability of the immobilized enzyme (Chávez-González et al. 2012).

The tannase showed best activity at $\mathrm{pH}$ 7.0. Comparison of activity of tannase with crude, purefied and immobilized tannase, demonstrated that immobilized tannase performed better at wide range of $(\mathrm{pH} 4.0$ 9.0). Crude tannase showed $40 \%$ activity at $\mathrm{pH} 5.0$ and purified tannase at the same $\mathrm{pH}$ showed $30 \%$ activity; whereas immobilized tannase exhibited $65 \%$ activity at $\mathrm{pH}$ 5.0. Similarly there was not much effect of $\mathrm{pH}$ on the immobilized enzyme between pH 7.0-9.0 (Fig. 5) under same condition the activity of crude and purified tannase dropped drastically. During immobilization process, enzymes are covalently bonded with the matrix or encapsulated with the porous matrix, which resulted in less micro environmental exposure for the enzyme when compared to the free enzyme. Hence, $\mathrm{pH}$ changes in the solution exhibit less impact to the immobilized enzyme activity due to improper environmental exposure; when compared to the free enzyme. This data is being supported by similar observations in $\beta$-Glucosidase immobilization studies (Tu et al. 2006; Figueira et al. 2011).

Anionic detergents such as SDS are known to increase residual activity of enzyme due to its ability to create negative charge in the active site of the enzyme. Purified tannase from S. lugdunensis exhibited $21 \%$ higher residual activity when compared with the controls (Fig. 6). Activity of enzymes that use metal ions as cofactors are drastically decreased in presence of EDTA, there was no drastic inhibition of S. lugdunensis tannase activity in presence of EDTA, suggesting this enzyme doesn't use metal ions as co-factor. In related to this tannase activity was not influenced in presence of common metal ions (Fig. 7). However at high concentration of metal ions, the tannase activity was decreased due to increase in ionic strength of the solution, which might affect the tannase native structure. Since tannase belong to serine group of enzymes (Mizuno et al. 2014), $\beta$-mercaptoethanol completely abolished the tannase activity (Fig. 6). Inhibition of tannase activity by $\beta$-mercaptoethanol has been reported earlier (Yao et al. 2014; Jiménez et al. 2014a).

Organic solvents play a major role in food industries. These solvents are useful to dissolve substrate completely and also some time they are known to enhance the activity of enzymes by modifying their structure in non-polar environment (Sharma and Kanwar 2014; Nie et al. 2016). In our studies, at $20 \%$, non -polar solvents such as hexane, toluene and benzene significantly, increased the activity of S. lugdanensis tannase (Fig. 8). However polar solvent such as methanol, DMSO, iosamyl alcohol and butanol inhibited the enzyme activity. It has been previously reported that polar compounds decrease the water content in and around the enzyme micro environment that could decrease the enzyme activity as observed by us (Nie et al. 2016). The ability of polar solvents to inhibit tannase activity and non polar solvents to enhance tannase activity are reported in Aspergillus awamori (Chhokar et al. 2010), Aspergillus carbonarius (Valera et al. 2015), Emericella nidulans, (Gonçalves et al. 2011) and in Enterobacter cloacae (Beniwal et al. 2010).

The reuse number of immobilized enzymes is standout amongst the most vital perspectives for industrial application. An increased stability could make the immobilized enzyme more advantageous than its free form (Huang et al. 2008; Gupta et al. 2014). Recombinant tannase immobilized with calcium alginates beads and its reusable activity $80 \%$ after six successful reuses and $50 \%$ activity after fifteenth cycle (Fig. 9). After each successful cycle, loss of protein from immobilized beads was tested by estimating the protein from supernatant by Bradford method and no significant protein was found in it. Based on this result, it is assumed that loss of activity occurs due to inactivation of enzyme caused by the denaturation (Gupta et al. 2014; Ye et al. 2006).

Tannase enzyme finds its applications in wide variety of industries and also in treatment of effluent from industries. For the first time, tannase from S. lugdunensis, has been cloned, over expressed and characterized in this study. This study also provides data for wide range application of tannase under different physiological conditions. More over immobilization studies demonstrate the recovery and re use of the enzyme which will reduce the cost of production. The potential of using the immobilized tannase in various industries and industrial effluent are in progress.

\section{Abbreviations}

ptanET 28a: recombinant pET 28a; IPTG: isopropyl $\beta$-D-1-

thiogalactopyranoside; SDS-PAGE: sodium dodecyl sulfate polyacrylamide gel electrophoresis; SDS: sodium dodecyl sulfate; EDTA: ethylenediaminetetraacetic acid; DMSO: dimethyl sulfoxide; CE: crude enzyme; PE: purified enzyme; IE: immobilized enzyme.

\section{Authors' contributions}

Planning and designing of study: AC, MA; experimentation: AC; result analysis: AC, MA; manuscript drafting: AC, MA. All authors contributed in the final approval of manuscript. All authors read and approved the final manuscript.

\section{Acknowledgements}

The authors thank Chancellor, VIT University, Vellore, Tamil Nadu, India for providing necessary laboratory facilities to carry out this work.

\section{Competing interests}

The authors declare that they have no competing interests.

\section{Ethical approval}

This article does not contain any studies with human participants or animals performed by any of the authors.

Received: 14 July 2016 Accepted: 28 September 2016

Published online: 04 October 2016 


\section{References}

Aguilar CN, Rodríguez R, Gutiérrez-Sánchez G, Augur C, Favela-Torres E, PradoBarragan LA, Ramírez-Coronel A, Contreras-Esquivel JC (2007) Microbial tannases: advances and perspectives. Appl Microbiol Biotechnol 76:47-59. doi:10.1007/s00253-007-1000-2

Beniwal V, Chhokar V, Singh N, Sharma J (2010) Optimization of process parameters for the production of tannase and gallic acid by Enterobacter cloacae MTCC 9125. J Am Sci. 6:389-397

Butler LG (1992) Antinutritional effects of condensed and hydrolyzable tannins. In: Hemingway RW, Laks PE (eds) Plant polyphenols. Springer, New York, pp 693-698

Buzzini P, Arapitsas P, Goretti M, Branda E, Turchetti B, Pinelli P, leri F, Romani A (2008) Antimicrobial and antiviral activity of hydrolysable tannins. Mini Rev Med Chem 8(12):1179-1187

Chávez-González M, Rodríguez-Durán LV, Balagurusamy N, Prado-Barragán A, Rodríguez R, Contreras JC, Aguilar CN (2012) Biotechnological advances and challenges of tannase: an overview. Food Bioprocess Technol 5:445-459. doi:10.1007/s11947-011-0608-5

Cherry JR, Fidantsef AL (2003) Directed evolution of industrial enzymes: an update. Curr Opin Biotechnol 14(4):438-443

Chhokar V, Sangwan M, Beniwal V, Nehra K, Nehra KS (2010) Effect of additives on the activity of tannase from Aspergillus awamori MTCC9299. App Biochem Biotechnol 160:2256-2264. doi:10.1007/s12010-009-8813-7

Curiel JA, Rodríguez H, Acebrón I, Mancheño JM, De Las Rivas B, Muñoz R (2009) Production and physicochemical properties of recombinant Lactobacillus plantarum tannase. J Agric Food Chem 57:6224-6230. doi:10.1021/jf901045s

de Figueira JA, Dias FFG, Sato HH, Fernandes P (2011) Screening of supports for the immobilization of $\beta$-glucosidase. Enzyme Res 2011:642460. doi:10.4061/2011/642460

Demain AL (2000) Small bugs, big business: the economic power of the microbe. Biotechnol Adv 18(6):499-514

Gonçalves HB, Riul AJ, Terenzi HF, Jorge JA, Guimarães LHS (2011) Extracellular tannase from Emericella nidulans showing hypertolerance to temperature and organic solvents. J Mol Catal B Enzym 71:29-35. doi:10.1016/j. molcatb.2011.03.005

Gupta A, Kumar V, Dubey A, Verma AK (2014) Kinetic characterization and effect of immobilized thermostable $\beta$-glucosidase in alginate gel beads on sugarcane juice. ISRN Biochem. 20:2014

Gurung N, Ray S, Bose S, Rai V (2013) A broader view: microbial enzymes and their relevance in industries, medicine, and beyond. BioMed Res Int 11:2013

Hatamoto O, Watarai T, Kikuchi M, Mizusawa K, Sekine H (1996) Cloning and sequencing of the gene encoding tannase and a structural study of the tannase subunit from Aspergillus oryzae. Gene 175(1):215-221

Huang XJ, Yu AG, Xu ZK (2008) Covalent immobilization of lipase from Candida rugosa onto poly (acrylonitrile-co-2-hydroxyethyl methacrylate) electrospun fibrous membranes for potential bioreactor application. Bioresour Technol 99(13):5459-5465

Iwamoto K, Tsuruta H, Nishitaini Y, Osawa R (2008) Identification and cloning of a gene encoding tannase (tannin acylhydrolase) from Lactobacillus plantarum ATCC 14917T. Syst Appl Microbiol 31:269-277. doi:10.1016/j. syapm.2008.05.004

lyer PV, Ananthanarayan L (2008) Enzyme stability and stabilization-aqueous and non-aqueous environment. Process Biochem 43(10):1019-1032

Jana A, Halder SK, Banerjee A, Paul T, Pati BR, Mondal KC, Das Mohapatra PK (2014) Biosynthesis, structural architecture and biotechnological potential of bacterial tannase: a molecular advancement. Bioresour Technol 157:327-340. doi:10.1016/j.biortech.2014.02.017

Jiménez N, Barcenilla JM, De Felipe FL, De Las Rivas B, Muñoz R (2014a) Characterization of a bacterial tannase from Streptococcus gallolyticus UCN34 suitable for tannin biodegradation. Appl Microbiol Biotechnol 98:6329-6337. doi:10.1007/s00253-014-5603-0
Jiménez N, Esteban-Torres M, Mancheño JM, de Las Rivas B, Muñoz R (2014b) Tannin degradation by a novel tannase enzyme present in some Lactobacillus plantarum strains. Appl Environ Microbiol 80:2991-2997. doi:10.1128/AEM.00324-14

Kumar M, Rana S, Beniwal V, Kumar R (2015) Optimization of tannase production by a novel Klebsiella pneumoniae KP715242 using central composite design \$. Biotechnol Reports. 7:128-134. doi:10.1016/j.btre.2015.06.002

Miura A, Giatti C, De Souza M, Bracht A, Kimiko M, Cristine A, Oliveira RF, Peralta RM (2013) Production of tannase and gallic acid by Aspergillus tamarii in submerged and solid state cultures. Afr J Biochem Res 7:197-202. doi:10.5897/AJBR12.073

Mizuno T, Shiono Y, Koseki T (2014) Biochemical characterization of Aspergillus oryzae native tannase and the recombinant enzyme expressed in Pichia pastoris. J Biosci Bioeng 118:392-395. doi:10.1016/j.jbiosc.2014.04.003

Neylon C (2004) Chemical and biochemical strategies for the randomization of protein encoding DNA sequences: library construction methods for directed evolution. Nucleic Acids Res 32(4):1448-1459

Nie G, Zhao R, Sun W, Gao Y, Zhu X, Zheng Z (2016) Enzymatic role of cyclic alkyl group in conformational instability of tannase. J Mol Catal B Enzym. 128:78-81. doi:10.1016/j.molcatb.2016.03.009

Noguchi N, Ohashi T, Shiratori T, Narui K, Hagiwara T, Ko M, Watanabe K, Miyahara T, Taira S, Moriyasu F, Sasatsu M (2007) Association of tannaseproducing Staphylococcus lugdunensis with colon cancer and characterization of a novel tannase gene. J Gastroenterol 42:346-351. doi:10.1007/ s00535-007-2012-5

Prakash K, John PJ (2011) Purification and characterization of tannase and tannase gene from Enterobacter sp. Process Biochem 46:240-244. doi:10.1016/j.procbio.2010.08.016

Ren B, Wu M, Wang Q, Peng X, Wen H, Mckinstry WJ, Chen Q (2013) Crystal structure of tannase from Lactobacillus plantarum. J Mol Biol 425:27372751. doi:10.1016/j.jmb.2013.04.032

Sharma S, Kanwar SS (2014) Organic solvent tolerant lipases and applications. SciWorld J. 2:2014

Sharma S, Bhat TK, Dawra RK (2000) A spectrophotometric method for assay of tannase using rhodanine. Anal Biochem 279:85-89. doi:10.1006/ abio.1999.4405

Taylor JP, Wilson B, Mills MS, Burns RG (2002) Comparison of microbial numbers and enzymatic activities in surface soils and subsoils using various techniques. Soil Biol Biochem 34(3):387-401

Tu M, Zhang X, Kurabi A, Gilkes N, Mabee W, Saddler J (2006) Immobilization of ??-glucosidase on Eupergit C for lignocellulose hydrolysis. Biotechnol Lett 28:151-156. doi:10.1007/s10529-005-5328-3

Ueda S, Nomoto R, Yoshida K, Osawa R (2014) Comparison of three tannases cloned from closely related lactobacillus species: L. plantarum, L. paraplantarum, and L. pentosus. BMC Microbiol 14:87. doi:10.1186/1471-2180-14-87

Valera LS, Jorge JA, Guimarães LHS (2015) Characterization of a multitolerant tannin acyl hydrolase II from Aspergillus carbonarius produced under solid-state fermentation. Electron J Biotechnol. doi:10.1016/j. ejbt.2015.09.008

Willner D, Daly J, Whiley D, Grimwood K, Wainwright CE, Hugenholtz P (2012) Comparison of DNA extraction methods for microbial community profiling with an application to pediatric bronchoalveolar lavage samples. PLOS ONE 7(4):e34605

Yao J, Guo GS, Ren GH, Liu YH (2014) Production, characterization and applications of tannase. J Mol Catal B Enzym 101:137-147. doi:10.1016/j. molcatb.2013.11.018

Ye P, Xu ZK, Wu J, Innocent C, Seta P (2006) Nanofibrous poly (acrylonitrileco-maleic acid) membranes functionalized with gelatin and chitosan for lipase immobilization. Biomaterials 27(22):4169-4176 